\title{
Portfolio Assessment Instruments of Illumination and Electricity Installation for Industrial Work Practice
}

\author{
$1^{\text {st }}$ Adi Sutopo ${ }^{1}, 2^{\text {nd }}$ Dadang Mulyana ${ }^{2}, 3^{\text {rd }}$ Azmi Riski Lubis ${ }^{3}$ \\ \{adisutopo64@gmail.com ${ }^{1}$ \} \\ Faculty of Engineering, Universitas Negeri Medan ${ }^{1,2,3}$
}

\begin{abstract}
The illumination and electrical installation portfolio assessment instrument aims to provide a competency assessment of industrial practical work activities which are part of the implementation of the MBKM curriculum in lecturing activities outside of tertiary institutions. Illumination and electrical installation portfolio assignments cover aspects of knowledge, attitudes, and motor skills. The development of portfolio assessment instruments is based on an analysis of the needs, situation, and condition of the industry as well as the availability of time. The portfolio assessment instrument consists of a general introduction, basic concepts, and portfolio assignments. Portfolio subtopics are arranged in an interconnected and sustainable unit so that the standards for assessing student competency achievement are measurable. Content validation by material experts and evaluation experts states that it is feasible to use, so that it can be used in the assessment of industrial practical work activities.
\end{abstract}

Keywords. MBKM curriculum, portfolio assessment, illumination, and electrical installation.

\section{Introduction}

The era of the industrial revolution 4.0 requires university graduates to have competencies that can face rapid social, cultural, work, and technological changes. These changes prompted the Ministry of Education and Culture to implement new policies in the implementation of higher education. The new policy that was launched was in the form of the "Kampus Merdeka Belajar Merdeka" program which was abbreviated as MKBM. The MKBM policy is related to the student learning process, namely to take part in learning outside the study program outside the campus for a maximum of 3 semesters [1].

One of the MKBM programs carried out off-campus is studying outside of non-university universities, namely in the industrial business world or in the community. In the industrial business world, it is in the form of work practices or internships, while in the community it is in the form of real work lectures $(\mathrm{KKN})$. The implementation of these activities is set for 6 months with a weight of 20 credits.

The implementation of these activities with a weight of 20 credits is not merely a work practice activity or KKN but is accompanied by course content that is relevant to industrial practice activities or KKN. This is intended so that students do not bear the heavy burden of credits with a large weight in one type of course. Therefore, it is necessary to have a policy on how to determine the types of courses that are under practical work activities or KKN, so that the achievement of CPL in the study program can be achieved. 
In addition to determining the types of courses that are following the CPL and related to the implementation of industrial practical work or KKN, it is also necessary to plan activities that are following the CPL of the relevant courses. The activities carried out must also be in line with what was done during the implementation of industrial work practices or KKN activities.

Activities carried out during industrial practical work that contains elements of developing skills and technology also need to be evaluated whether they can really achieve the CPL that has been determined by the study program. Therefore we need an instrument that can measure the level of achievement of the implementation of industrial practical work activities. This research will focus on how to measure the level of achievement in the implementation of industrial practical work activities by developing portfolio instruments, especially for illumination courses and electrical installations.

Implementation of the MKBM curriculum in learning outside universities, namely in industry. The form of activity in the industry that is in line with the curriculum of the Electrical Engineering Study Program is Industrial Practice. The goal is to prepare graduates who are strong in facing developments and changes in the social, cultural, work, and technological world in the era of the industrial revolution 4.0. Based on the guidelines for implementing the MKBM curriculum from the Ministry of Education and Culture that the implementation of activities outside of tertiary institutions in this case in the industry, namely internships/practical work is equivalent to 20 credits which are carried out for 6 months [1].

The weight of independent learning activities in independent campuses in the industry is grouped into two, namely free form and structured form [1]. The Electrical Engineering study program tends to adhere to a structured form of 20 credits expressed in the form of equivalence to the courses offered whose competencies are in line with internships/industrial practical work. One of them is the subject of illumination and electrical installation which is always present in the industry.

The implementation of the MBKM curriculum in the Electrical Engineering Study Program, FT Unimed, refers to the Common Criteria and Criteria Guide version 2020 for Engineering Programs IABEE. Criterion 1 in the general criteria regarding undergraduate competency orientation states that the program is Ability to apply methods, skills, and modern engineering tools necessary for engineering practices, Ability to communicate effectively in oral and written manners, Ability to plan, accomplish, and evaluate tasks under given constraints, Ability to work in multidisciplinary and multicultural teams [2]. Based on these criteria, the student learning activity program must be able to achieve the expected competencies, namely: skill ability in anticipating technological developments, modern engineering, communicating in writing and orally, able to plan, complete, and evaluate as well as ability in multidisciplinary teams.

The achievement of competence in Industrial Work Practice activities needs to be assessed that can provide an overview of the extent to which students achieve the specified competencies. The level of competency achievement must be measurable using an assessment instrument. Because the implementation of industrial practice work is carried out outside the campus so that lecturers have limitations in interacting with students, a flexible assessment instrument is needed but can measure the competence of the student. One form of assessment that is considered to be able to assess the competence of courses that are integrated with industrial practice activities is to use portfolio assessment.

Osman Birgin, and Adnan Baki [3] describe the portfolio as a systematic and purposeful collection of evidence that reflects the success, performance, and efforts of the students in one or more areas over a period of time. Based on this definition, a portfolio can assess a person's 
performance and efforts in a certain period of time to see his success. In line with this definition, the portfolio consists of various forms of evidence of learning success as stated by Davis, Margery H, Gominda G Ponnamperuma, et al, [4], and Lahmer Mokhtaria[5] a portfolio is a collection of various forms of evidence of achievement of learning outcomes, likes work progress and responsibility.

Portfolios have the advantage of assessing that they can reflect various abilities. Cain, M, et.al (2005) said that the skill of reflection involves the ability to effectively use high-level cognitive skills such as critical and creative thinking, problem-solving, and decision-making, as well as the ability to tap into affective areas and articulate thoughts and feelings. Portfolio assignments reflect students' cognitive, affective and articulate thoughts and feelings.

Lahmer Mokhtaria [5] states that the steps in compiling a portfolio are: Stating the Philosophy, Evidence Collection, Planning, and Preparation: Assessment and Examination; Shaping and Organizing. The basis for compiling a portfolio is the philosophy of the courses to be assessed, how to assess them, what is the evidence of success and how to provide assessments that reflect student abilities.

Portfolio assessment has many advantages such as reducing subjectivity, which can be in the form of qualitative or quantitative, can assess performance in applying knowledge or theory, can assess attitudes, can reflect the development of student learning outcomes, can diagnose student strengths, and weaknesses. In addition to the advantages of portfolio assessment, it also has disadvantages, including the documents submitted by students may not be their own work, it takes a long time to assess because of the large number of documents. However, the assessment must be following the principles of assessment, namely; educative, authentic, objective, accountable, and transparent [6].

Portfolio assessment as one of the assessment instruments needed in the implementation of the MKBM curriculum is that students get the freedom to study outside of college for 6 months with a weight of 20 credits. Study outside of university can be done in the industry in the form of Industrial practical work. The implementation of industrial practical work activities can be integrated with several relevant supporting courses. Thus the burden of 20 credits of studying in the industry can be divided into several courses. One of the courses that are very close to the conditions and the industrial environment is the illumination and electrical installation with a weight of 3 credits.

Illumination and electrical installation are one of the courses of expertise in the electrical engineering study program, so that every electrical engineering student must be able to achieve the expected competencies. The achievement of illumination and electrical installation competencies that electrical engineering students must master are cognitive, affective, and psychomotor abilities in terms of analyzing, planning, and carrying out electrical and illumination installations in industry and residential homes according to PUIL standards and other electrical regulations.

Based on this, it is necessary to develop a portfolio assessment that can assess the achievement of student competencies while carrying out industrial practical work activities. Portfolio assignments are based on illumination and electrical installations that can be observed, analyzed, planned, and evaluated in the industry. The billing for portfolio assignments adjusts the learning plan for illumination and electrical installations that have been prepared by the lecturer in charge of the course. 


\section{Method}

This research was carried out at the Department of Electrical Engineering Education, Faculty of Engineering, UNIMED in 2021. Development of the instrument portfolio of illumination and electrical installations for the conversion of the value of industrial practical work activities in this study used Research and Development (R \& D) from Gall, namely to build an assessment instrument with a portfolio model approach for illumination and electrical installation lectures in industrial practical work activities. The research procedures carried out include: needs analysis, assessment of the portfolio of illumination and electrical installations, feasibility studies, planning to build a model, and building a model portfolio of illumination and electrical installations, testing a limited portfolio of assessments, and completing the portfolio of assessments of illumination and electrical installations.

Data collection techniques in this study used instruments in the form of observation guidelines, content analysis of illumination materials, and electrical installations and documentation guidelines. The required data collection is carried out by developing instruments related to the feasibility level of the illumination and electrical installation portfolio assessment instrument.

Observation guidelines are used to capture the extent of the implementation of illumination and electrical installations in industrial environments, so that they can be used as material in the preparation of the required Instrument portfolio materials. The material content checklist analysis is used to balance and adjust the concept of illumination and installation in the development of science and technology. Documentation guidelines are needed to provide guidelines for observation, conversion of industrial practical work activity assessments with lighting and electrical installation portfolio assessment instruments. The grid in the preparation of portfolio assessment instruments as a guide in preparing the illumination and electrical installation portfolio assessment instruments.

Assessment instrument for feasibility test Instrument for assessment of the portfolio of illumination and electrical installations by material experts and evaluation experts. The material content assessment instrument was developed to determine the quality of the learning material from the aspect of the assessment coverage based on the illumination and electrical installation CPMK. Material expert validators in reviewing the feasibility of portfolio assessment are based on aspects: content feasibility, language, presentation, and usefulness. The level of feasibility of portfolio assessment by evaluation experts with assessment indicators covering aspects of (1) appearance, (2) easy of use, (3) consistency, (4) format, and (5) graphics.

\section{Result and Discussion}

\subsection{Needs Analysis}

The findings of Strengths and Difficulties Questionnaire (SDQ) before and after the investigation revealed:

a. Based on the CPMK of illumination and electrical installation, the need for assessment in the form of a portfolio consists of the following sub-sections: 1) safety of electrical installations; 2) Electrical installation equipment Lighting and power; 3) 
Power installation equipment; 4) Planning of lighting and power installations; 5) Electrical machinery installation; 6) grounding installation; 7) Administration workspace illumination; 8) machine workspace illumination, and 9) Illumination Planning.

b. Industrial situation and conditions: lighting installations for administrative and document workspaces, staff workspaces, employee workspaces, and company/industrial outdoor spaces.

c. Industrial situation and conditions: power installation and electrical machinery installation

d. Students can directly observe, analyze lighting and power installations in the industry

e. The results of observations and analysis become the basis for students to be able to plan lighting and power installations as well as illumination according to space requirements

f. The period of implementation of industrial work practice activities is 6 months or approximately 22 days x 6 months.

\subsection{Portfolio Planning.}

Portfolio assignments are divided into 16 parts based on the CPMK which includes 12 subsections. Each portfolio consists of a general description section or concept that will be covered in the portfolio assessment.

\subsubsection{Development of portfolio assessment}

a. Needs analysis

b. The situation of the building and the type of work in the industry/company

c. Availability of student time and opportunities to carry out industrial practice activitie

The portfolio assessment is structured to provide an assessment of the extent to which students master the CPMK of Illumination and Electrical Installation in the industry. This is because the electrical installation and illumination in the industry are already comprehensive. After all, the electrical installation and illumination include the installation and illumination of lighting for administrative workspaces, staff, and production workspaces involving various production machine tools.

Based on this, the portfolio assessment includes: 1) electrical installation safety; 2) Lighting and power electrical installation equipment; 3) Power installation equipment; 4) security system for lighting and power installations; 6) Planning for lighting and power installations; 7) Installation of electrical machinery; 8) grounding installation; 9) Basic concept of illumination; 10) Illumination of the administrative workspace; 11) machine workspace illumination, and 12) Illumination Planning.

The portfolio assessment is divided into three parts, namely a brief introduction, basic concepts, and portfolio assignments. The introduction contains a general introduction to the topic to be discussed, namely providing an explanation of the topic on the development of science and technology related to the problem. Thus, students have an overview of the future development of science and technology in the topics discussed.

The basic concept contains the concepts of knowledge and technology related to the topic of the problem. Based on these basic concepts, students can formulate problems on the topics 
to be discussed. This encourages students to think comprehensively by linking previous topics in the problem-solving analysis process.

Portfolio assignments are a core part of portfolio assessment. Assignments on each topic do not stand alone but are interconnected with the previous topic so that at the end students are expected to have mastered all CPMK illumination and electrical installations. Portfolio assignments are given in the form of questions, problem-solving, project assignments which include planning and if possible up to the implementation stage. The schematic of the instrument development model for the lighting and electrical installation portfolio is shown in Figure 1.

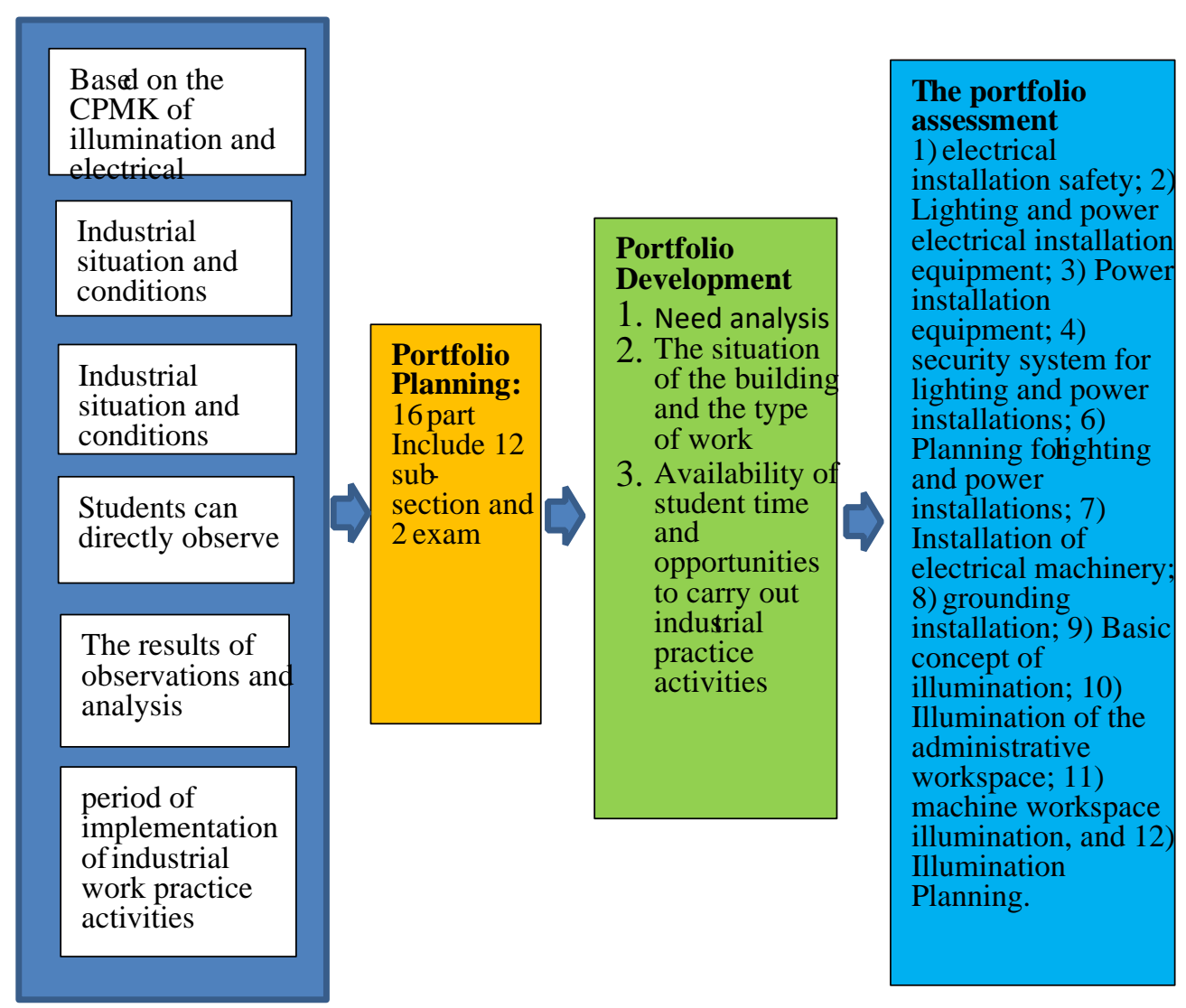

Fig. 1. The schematic of the instrument development model for the lighting and electrical installation portfolio.

The results of the evaluation of the material expert and evaluation expert valid. The validity of the results of this study was only carried out using content validity and form validity. Table 1 shows the results of the assessments from material experts and evaluation experts. 
Table 1. Validator assessment results.

\begin{tabular}{lccll}
\hline No & Validator & Average & Range Value & Description \\
\hline 1 & material experts & 74,5 & $>69,4$ & Very Worthy \\
2 & evaluation experts & 45 & $>43,34$ & Very Worthy
\end{tabular}

The implementation of the Merdeka Learning Independent Campus (MBKM) curriculum provides students with the opportunity to do practical work in the industry for 6 months with 20 credits recognized. The recognition of these 20 credits can be converted into several courses relevant to industrial practice ape activities. One of the relevant courses is the illumination and electrical installation because industrial practical work activities in industry/companies will be in direct or indirect contact with illumination and electrical installations. Therefore, students must be able to understand, analyze and plan lighting and electrical installations in the industry based on the results of observations, practices, and measurements in the industrial environment.

Lecturers will have difficulty in assessing the competency achievement of students who work in industrial practice. This is because the opportunity for lecturers to provide daily assessments, midterm and final exams, or in assessing student skills in the field of illumination and electrical installation directly is very limited. Therefore, an assessment tool is needed that can assess students' ability to understand, analyze and plan lighting and electrical installations in the workplace.

Assessment of the level of student competency achievement in taking courses in theory or practice can be done in several forms of assessment such as objective or subjective tests, inventory, adaptive tests, and portfolio assignments. Adaptive tests and portfolio assignments are known as authentic forms of assessment. The portfolio should be a strategic, planned document of tasks, learnings, and accomplishments, presented in a way that it becomes a marketing tool for future employment opportunities and not merely a summative assessment [7]. In addition, this form of assessment provides an assessment of someone according to their level of ability [8]. Portfolio assessment also has high flexibility that can be applied in all learning situations. the use of portfolios for assessment raises issues of reliability, the timeconsuming nature of assessment, objectivity, and authenticity of the work [9].

The basic principle of portfolio assessment is a collection of student assignments that are integrated and can show the gradual development of student abilities which ultimately form a complete (comprehensive) competency. Overall portfolios are seen as a positive form of assessment as they develop a learner in a more holistic and integrative way [8]. Portfolio assessment enables students to reflect their real performance, to show their weak and strong domain and to observe student's progress during the learning process, and encourages students to take responsibility for their own learning [1].

The scope of illumination and electrical installations is quite broad, starting from an understanding of safety, utility of equipment and its components, execution of work, and planning analysis. Based on this, portfolio assignments are arranged in stages and are interrelated between portfolio assignments with one another. The results of the development of portfolio assignments obtained 12 assignments and based on the results of the validation of material experts and evaluation experts, they met the very feasible criteria. These 12 portfolio assignments are viewed in terms of the scope of the material, the ease of implementation of the assessment, the elements of the assessment, the availability of time in completing portfolio assignments during the implementation of industrial practical work activities (each portfolio assignment can be done for 2 weeks). E-portfolios enhanced with learning analytics, might 
increase the quality and efficiency of workplace-based feedback and assessment in professional education [10].

\section{Conclusion}

Development of a portfolio of lighting and electrical installation assignments based on the learning outcomes of the courses, the conditions and situations of the industry/company, and the time allocation for the implementation of industrial practical work Development of the portfolio of illumination and electrical installation tasks into 12 portfolio sub-tasks that can assess knowledge, attitudes, and psychomotor abilities. Portfolio assignments as authentic assessments can provide a comprehensive assessment of the ability to achieve student competencies in carrying out industrial practical work.

\section{References}

[1] Direktorat Jenderal Pendidikan Tinggi Kementerian Pendidikan dan Kebudayaan. Buku Panduan Merdeka Belajar - Kampus Merdeka. Jakarta: Direktorat Jenderal Pendidikan Tinggi Kemdikbud RI; 2020.

[2] IABEE. Common Criteria and Criteria Guide for Engineering Programs. 2020.

[3] Birgin O, Adnan B. The Use of Portfolio to Assess Student's Performance. Journal of Turkish Science Education. 2007; 4(2): 75-90.

[4] Davis MH, Ponnamperuma GG. Portfolio Assessment. Journal of Veterinary Medical Education. 2005; 32(3): 279-284.

[5] Lahmer M. The Use Of Portfolio As An Assessment Tool. International Journal Of Scientific \& Technology Research. 2015; 4(7).

[6] Direktorat Jenderal Pembelajaran Dan Kemahasiswaan Kementerian Riset, Teknologi Dan Pendidikan Tinggi. Panduan Penyusunan Kurikulum Pendidikan Tinggi Di Era Industri 4.0. Jakarta: Direktorat Jenderal Pembelajaran dan Kemahasiswaan Kementerian Riset Teknologi dan Pendidikan Tinggi; 2018.

[7] Scholtz D. Assessing workplace-based learning. International Journal of Work- Integreted Learning. 2020; 21 (1): 25-30.

[8] Guard N, Richter U, Waller S. Portfolio assessments. 2016.

[9] Wagner Z. M. Portfolio assessment in vocational education: the assessor's view. Australian Journal of Teacher Education. 1998; 23(2): 41-49.

[10] Schaaf VDM, Moonen VLJ, Eric D, Olle TC, Atta B. Improving workplace-based assessment and feedback by an E-portfolio enhanced with learning analytics. Education Tech Research Dev. 2017; 65:359-380. 